Веран Ј. СТАНОЈЕВИЋ ${ }^{*}$ Универзитет у Београду Филолошки факултет
Оригинални научни рад

Примљен: 14.10 .2019 . Прихваћен: 12.02.2020.

\title{
НЕКИ АСПЕКТИ УПОТРЕБЕ ЛЕКСЕМЕ ЈЕДАН У РАЗГОВОРНОМ ЈЕЗИКУ И ФРАНЦУСКИ ПРЕВОДНИ ЕКВИВАЛЕНТИ ${ }^{* *}$
}

У раду испитујемо ненумеричку употребу лексеме један у функцији детерминатива. Полазећи од француских преводних еквивалената облика један испитујемо својства по којима овај облик показује одлике француског неодређеног члана.

Кључне речи: лексема један, основни број, неодређени члан, семантика, српски језик, француски језик.

\section{1. Увод}

Познато је да је лексема један категоријално поливалентна, односно полифункционална реч (в. Ивић 1971, Чудомировић 2012). Она се, наиме, може употребити било нумерички, било ненумерички. У нумеричкој функцији лексема један је основни број. Контексти који намећу недвосмислено нумеричко читање овог облика су следећи:

1. Присуство неког другог основног броја: Један, два, три / Купио сам једну књигу, а не две.

2. Употреба неког нумеричког модификатора: бар, највище, тачно: Направио је бар/највише/тачно једну грешку.

3. Употреба неког компаративног израза: више од, мање од: Направио је више од једне грашке.

4. Употреба рестриктивног адверба само: Направио је само једну грешку.

\footnotetext{
*veranva@gmail.com

** Овај рад је настао у оквиру пројекта бр. 178014, Динамика структура савременог српског језика, који финансира Министарство просвете, науке и технолошког развоја Републике Србије.
} 
Поред нумеричке, лексема један може имати и ненумеричку употребу у којима, самим тим, она нема статус основног броја. Наиме, у ненумеричкој функцији лексема један може бити:

a) Придев, ако се може заменити придевом исти или једнак без разлике у значењу: Једна мајка их је однеговала. (=иста); Ваши и наши народи су кроз векове били једне среће. (=једнаке, исте). ${ }^{1}$

б) Именичка заменица, ако се употреби самостално, при чему се из контекста види да је тип референта² познат учесницима у комуникацији, нпр. Хајде, попиј једну.

в) Придевска заменица, као у примеру Попео се на једно брдо, где један није ни број, ни придев ни именичка заменица, него уводи за саговорника нов, претходно непоменут референт.

Да би се одредио категоријални статус лексеме један, често се мора узети у обзир и ванјезички контекст, као у следећем примеру: Купио сам једну књигу. Наиме, у зависности од комуникативне намере говорника, облик једну тумачиће се овде: или као број, или као придевска заменица. Наиме, ако желим да обавестим свог саговорника о броју књига које сам купио (нпр. у ситуацији у којој он зна да сам ишао у куповину књига), лексема један биће основни број, а ако ми је пак циљ да у дискурс уведем нов ентитет (књигу) о којем намеравам нешто ново да му саопштим (нпр. у ситуацији у којој мој саговорник не зна да сам био у куповини књига), онда ће се један тумачити ненумерички - али не као придев или именица, него као придевска заменица. Неки аутори, попут М. Стевановића, овај тип ненумеричких употреба лексеме један доводе у везу са употребама неодређеног члана у језицима са чланским системом: „Број један се врло често у нашем језику употребљава - не да се њим означи број, него више као нека врста неодређеног члана" (Стевановић 1981: 313). ${ }^{3}$ Павица Мразовић лексему један третира као детерминатив (Мразовић 2009: 288). По овој ауторки лексема један у рематској позицији има функцију члана, па се, сматра она, може заменити обликом неки као у примеру Чека те једна/нека жена. (Мразовић 2009: 289).

Ми ћемо се у овом раду усредсредити на ненумеричку упоребу облика један са статусом придевске заменице. У анализи користимо термин 'детерминатив један' или 'лексема један у детерминативној функцији'. Полазећи од француских преводних еквивалената овог облика, испитаћемо она својстава по којима овај облик показује одлике француског неодређеног члана. Истраживање смо спровели полазећи од примера ексцерпираних из паралелног корпуса ParCoLab (Parallel Corpus for Serbian, French and English) ${ }^{4}$, и то оног

\footnotetext{
${ }^{1}$ Погледати у: Ђурић (2019: 11).

${ }^{2} \mathrm{Tj}$. ванјезичког ентитета на који подразумевана именица упућује.

${ }^{3}$ Чудомировић (2012: 320) указује и на став Томе Маретића о употребама облика један „,bez ikakve potrebe prema njemačkom artikulu ein, franc. un, tal. uno" (Maretić 1963: 510).

${ }^{4}$ Реч је о корпусу упарених текстова на француском, српском, енглеском, а однедавно и на окситанском, који броји преко 13 милона речи и који је резултат заједничког пројекта Универзитета у Београду и Универзитета у Тулузу. Корпус је бесплатно доступан на сајту: http://parcolab. univ-tlse2.fr/.
} 
дела овога корпуса који је најближи спонтаном разговорном језику, а то су транскрипти домаћих филмова преведених на француски језик.

\section{2. Корелација један-ип}

Пошто у француском језику постоји члан као врста речи, а лексема један у детерминативној функцији показује одређену сличност са неодређеним чланом, поћи ћемо од питања да ли и у којој мери облик један и француски неодређени члан иn корелирају као могући преводни еквиваленти, тим пре што обе форме, зависно од контекста, у испитиваним језицима могу бити и основни бројеви (као у примерима 1-4) па су тада потпуно еквивалентни. ${ }^{5}$ Ово последње практично значи да ће се један као основни (кардинални) број на француски увек преводити обликом ип као основним бројем, и обрнуто, тј. кардинални број иn на српски ће се увек преводити бројем један. Следећи примери илуструју поменуту преводну еквиваленцију у смеру од српског ка француском:

(1) Ево још један шахић. „У плавоме сну.” / Et en voilà un autre échec. „Dans le rêve bleu."

(2) Зовем се Малик Малкоч, али ме нико не зове само Малик. Него, сви кажу: „Малик, Малик, на говно си налик.” Родио сам се 2. новембра 1944, а мама је написала да сам се родио 29. октобра, тј. три дана раније зато што је био рат, и зато што смо били сиромашни па да добије још један доплатак на онај мјесец кад се ја уствари нисам ни родио. Јожа је мој најбољи друг, ал' се не зове тачно Јожа него Серјожа Петровић. / Je suis Malik Malkoc, mais on ne m'appelle pas Malik. On dit: „Malik, Malik, voilà le hic.” Je suis né le 2 novembre 1944 mais ma mère m'a déclaré le 29 octobre, c'est-à-dire trois jours plus tôt, parce que c'était la guerre, et comme on était pauvres, c'était pour avoir un supplément pour ce mois précédent alors que je n'étais pas encore né Joza est mon meilleur ami ; en fait, son vrai nom est Serjoza Petrovic.

(3) Морамо нешто да попричамо са овом тетом. Један, два, три, сад! Добро. / On doit lui dire deux mots à cette dame. Un, deux, trois, allez ! Bien.

(4) А сада, поштовани посетиоци, дошао је тренутак да са посебним задовољством најавим звезду вечерашњег програма, дражесну Доли Бел! Још један аплауз за Доли Бел! / Et maintenant, chers invités, le moment est venu de présenter l'étoile de la soirée, la charmante Dolly Bell. Bravo pour Dolly Bell!

\footnotetext{
${ }^{5}$ На дијахронијском плану, наиме, француски неодређени члан води порекло од основног броја $и$.
} 
Међутим, како је употреба лексеме један час факултативна, као у примерима (5)-(7) 6 , час теже прихватљива (ако је уопште прихватљива), као у примерима (8)-(10), при чему ће се у француском језику као преводни еквивалент употребити именица са неодређеним чланом, јасно је да ови облици нису апсолутни корелати. Наиме, из ових примера се види да именичкој синтагми са неодређеним чланом у француском може одговарати и недетерминисана именица у српском.

(5) Јасно! Ово је (један) фин дечко, немаш шта да бринеш. / C'est clair. C'est un bon garçon.

(6) Мирза ми је показао то на карти гђе је то на једној ријеци Дрини гђе се гради (једна) велика фабрика струје што се зове хидроцентрала. / Mirza m'a montré sur la carte, c'est sur la rivière Drina, où on construit une usine d'électricité qu'on appelle une centrale hydraulique.

(7) Е, мој пријатељу, јуче је јуче, а данас је данас. Имаш (једну) цицару? Имам, ево. / Cher ami, hier c'était hier et pas aujourd'hui. Tu as une sèche ? Voilà, tiens.

(8) Татин брат. Брицо. А може да обрезује и прави доктор. / Le frère de papa. Un barbier. $U n$ docteur aussi peut le faire.

(9) Куда ћеш с тим животињама. Доле није зоолошки врт, већ склониume за људе. / Où emmènes-tu ces animaux? Ma cave est un abri, pas un zoo. Je ferme.

(10) Шта сте ово урадили? Он је био комуниста. / Qu'est-ce que vous faites? C'était un communiste!

Да апсолутне корелације између један и француског неодређеног члана $и n$ нема, сведоче и случајеви у којима се француски неодређени члан употребљава као еквивалент придевске заменице неки, као у следећим примерима: ${ }^{7}$

(11) Људи, не можемо да је пустимо саму. Чекај, можда успут нађемо неки такси! Можда мазнемо неки превоз... / On ne peut la laisser y aller seule. Attends, on trouvera peut-être un taxi en chemin ! Ou piquer un autre moyen de transport...

(12) Кажи: „Јавићу се за пет минута.” Хајде, кажу неки глумаи хоће да запали позориште. А тебе хоће да убије. / Dis-leur que je rappellerai dans cinq minutes. Un des acteurs veut mettre le feu au théâtre.Et il menace de te tuer.

(13) Станиславе, овде нема гријања. Молим те, тражи да нас преместе у неки други хотел. Враћам се ја брзо. / Stanislav, il n'y a pas de chauffage. Dis-leur de nous trouver un autre hôtel. Je reviens vite.

\footnotetext{
${ }^{6}$ Факултативност (тј. необавезност) ове лексеме, коју су потврдили наши информанти, бележимо заградама.

${ }^{7}$ Наиме, француски неодређени члан неутралан је у погледу познатости референта за говорника, тако да се он може употребити као преводни еквивалент како облика један тако и облика неки. О томе говоримо у наредном одељку овога рада.
} 
(14) Тата! Не, не дели сам друг Тито дивљач, не, него неки тип са брковима, из протокола. / Non, ce n'est pas le camarade Tito qui distribue le gibier, c'est un type moustachu du Protocole qui le fait.

Међутим, ако пођемо од ефективно реализованог детерминатива један у српском, односно, ако занемаримо његов евентуално факултативни карактер - на који указују већ претходно поменути примери $(5-7)^{8}$ - можемо очекивати да ће се у највећем броју случајева као француски еквивалент облика један у детерминативној функцији употребити управо неодређени члан, тим пре што је детерминатор у француском (француски термин déterminant) обавезан елемент именичке синтагме. Ако је неодређени члан једини преводни еквивалент детерминатива један, а он то јесте, онда се може претпоставити да овај последњи има (бар неке) одлике неодређеног члана. Питање на које ћемо покушати да одговоримо у следећем одељку овога рада јесте следеће: Шта је заједничко француском неодређеном члану и детерминативу један?

\section{3. Својства заједничка детерминативу један и француском неодређеном члану}

И неодређени члан ип и лексема један уводе у дискурс за саговорника нов (тј. претходно непоменут и у том смислу непознат) референт. Следећи примери из нашег корпуса илуструју ово фундаментално својство како неодређеног члана у француском, тако и лексеме један у српском језику.

(15) Господине, ми смо драмски уметници из Београда, и идемо на турнеју у тај Србобран. Господине, ми смо позвани у Републику Српску да изведемо један уметнички програм. - Nous sommes des comédiens de Belgrade en route vers Srbobran. Monsieur, nous avons été invités pour donner des représentations en République serbe.

(16) Он може час посла да се увуче међу нас. Још нешто. Има једна песма коју ћемо сви морати да научимо напамет и коју ћете током марша често певати. Il peut s'infiltrer dans nos rangs en un clin d'œil. Encore une chose. Il y a une chanson que vous devez tous apprendre par cœur, car vous la chanterez souvent pendant la Marche.

Референт може бити познат говорнику, што се може и експлицитно сигнализовати као у следећем примеру са релативном реченицом „коју не бих сада да именујем":

(17) Нарочито бих хтео да нагласим да су ми од тебе дражи и моји другови, једна девојчийа коју не бих сада да именујем, и још нешто: (...). - Je voudrais particulièrement souligner que je te préfère mes copains,

\footnotetext{
${ }^{8}$ Факултативност лексеме један коју смо констатовали у неким случајевима, представља, по нама, основни аргумент у прилог општеприхваћеном ставу да један није члан у српском. Наиме, у језицима који имају члански систем, какав је француски, члан се мора употребити у одсуству неког другог детерминатора.
} 
et une fille que je ne nommerais pas maintenant. Encore une chose : $(\ldots)$.

Занимљива је употреба детерминатива један у примеру под бр. (18) где говорник синтагмом једној ријеци Дрини сигнализује да је њему некада (као саговорнику дотичног Мирзе) река Дрина била непозната. Овде се, наиме, непознатост референта (на коју указује облик један) транспонује у прошлост уз делимично прекомпоновање улога учесника у комуникацији. Наиме, употребом детерминатива један локутор саопштава, поред осталог, да му је некада, као саговорнику дотичног Мирзе, референт именичке синтагме био непознат.

(18) Мирза ми је показао то на карти гђе је то на једној рuјеции Дрини гђе се гради једна велика фабрика струје што се зове хидроцентрала. Mirza m'a montré sur la carte, c'est sur la rivière Drina, où on construit une usine d'électricité qu'on appelle une centrale hydraulique.

Овде је важно уочити и то да у француском језику аналогна транспозиција у прошлост непознатости референта за саговорника није могућа употребом неодређеног члана. Не чуди стога што је у преводу на француски употребљен одређени члан уз именицу rivière сигнализујући само то да је овде реч о ентитету који је јединствен у својој врсти 9 .

Већ смо констатовали да детерминатив један указује на то да референт именичке синтагме није познат саговорнику. У вези с тим је и следеће својство које је заједничко облику један и француском неодређеном члану, а то је њихова неутралност у погледу епистемичког статуса референта за говорника (уп. Станојевић 2013: 64). Наиме, референт може а не мора бити непознат и говорнику. У досад анализираним примерима контекст сугерише да је референт познат говорнику. То, међутим, није нужно. Наиме, у примеру Један певаи запевао у брдима, у којем се један може заменити лексемом неки, тешко је замислити да говорно лице зна о којем је петлу реч.

У многим до сада анализираним примерима детерминатив један се може изоставити а да то не наруши синтаксичку прихватљивост реченице и не промени семантичку интерпретацију синтагме (непознатост референта за саговорника). Међутим, ако је детерминатив један синтаксички факултативан, он није нужно и семантички факултативан. Семантичка обавезност значи да би се изостављањем облика један променила интерпретација именичке синтагме, тако да њоме означен референт не би више био непознат саговорнику. Синтагме које уводе познат референт (за саговорника) јесу одређене именичке синтагме. Треба имати на уму да није свака одређена синтагма и референцијална $^{10}$ (в. Станојевић 2010: 124), али и то да свака синтагма која уводи

\footnotetext{
${ }^{9}$ Наиме, постоји само једна река Дрина и то је све што се одређеним чланом саопштава.

${ }^{10}$ На пример, у француском као језику с чланским системом синтагме са одређеним чланом могу бити и генеричке (нпр. Le chien est un animal domestique.), а генеричке употребе су нереференцијалне.
} 
саговорнику познат референт - мора бити одређена. ${ }^{11}$ Одређеност именичке синтагме јесте, дакле, нужан али не и довољан услов за познатост њом уведеног референта. ${ }^{12}$ Погледајмо следећи пример у којем је лексема један семантички обавезна а синтаксички факултативна:

(19) Сад се ово носи као штос. Један мој друг је платио две марке за Орден народног... Немој ово да продаш. - C'est vachement cool ! Un copain a payé deux marks pour une médaille de héros... Ne les vends jamais.

Синтагма један мој друг из примера (19) означава особу која, по природи ствари, локутору мора бити позната. Детерминатив један сигнализује да је дотична особа (тј. мој друг) непознат саговорнику. Међутим, иако синтаксички факултативан, облик један то није и семантички, јер би његово изостављање значило да особа на коју реферише синтагма мој друг није непозната саговорнику. Можемо, дакле, рећи да је лексема један обавезна уколико би се њеним изостављањем променила интерпретација (у смислу познатост-непознатост референта) именичке синтагме. Овде треба имати у виду да синтаксичка факултативност не имплицира семантичку факултативност детерминатива један, док се обрнуто подразумева: семантички факултативан облик један мора бити и синтаксички факултативан. Другим речима, синтаксичка факултативност је нужан, али не и довољан услов за семантичку факултативност, тј. за испустивост лексеме један. ${ }^{13} \mathrm{У}$ француском је ситуација једноставнија пошто је члан у овом језику синтаксички обавезан ${ }^{14}$, тако да се питање његове семантичке факултативности и не поставља.

Из досадашњег разматрања произилази да референт именичке синтагме уведене детерминативом један мора бити непознат саговорнику било да је он познат или непознат говорнику.

Поменимо овде и то да комбинације ,jедан + посесив + именица" неретко имају и партитивну интерпретацију ('један од') која подразумева плуралност скупа индивидуа из којег се издваја једна, за саговорника непозната индивидуа:

(20) Шта је било? Ма један мој глумац. Прети да ће да се убије. Па нек се убије, заболе те. - Qui c'était ? Un de mes acteurs. Il menace de se suicider. Qu'il se suicide.

(21) На пример, да ти високо краљевство ниси узео светлу Марију, не би у Србији данас предел Северина био. Или да један твој син никакав

\footnotetext{
${ }^{11}$ Наиме, није природно употребити властито име уколико знамо да саговорнику није позната особа коју тим именом означавамо. У другим случајевима познатост референта произилази из његове претходне поменутости у дискурсу. Тако, на пример, особа на коју реферише синтагма mај студент не мора бити позната саговорнику, али мора бити претходно поменута, тј. претходно уведена у дискурс.

${ }_{12} \mathrm{O}$ односу одређеност (неодређеност)/познатост (непознатост) погледати у Станојевић (2010).

${ }^{13}$ О случајевима обавезности и факултативности лексеме један погледати у: Ивић 1971: 104-107.

${ }^{14}$ Будући да се не може изоставити, а да то не наруши синтаксичку прихватљивост именичке синтагме у француском.
} 
предел од Грка не добије или други син никакав предел од Бошњака, како би далеко Србија отишла.То, брате Србине! - Par exemple, si votre haut royaume n'avait pas accueilli la vénérable Marie, la Serbie n'aurait pas de région Severina. Si l'un de tes fils recevait une région des Grecs, un autre de tes fils, une région des Bosniaques, la Serbie serait tellement vaste ! Vas-y, mon frère !

За разлику од француског језика у којем је неодређени члан једини маркер непознатости референта за саговорника, у српском се у овој функцији употребљава и лексема неки. Међутим, облик неки се разликује од облика један, а самим тим и од француског неодређеног члана, по томе што неки није неутралан у погледу епистемичког статуса референта за говорника. Познато je, наиме, да придевска заменица неки сигнализује да је референт именичке синтагме непознат не само саговорнику, него и говорнику (Чудомировић 2012: 325-326, Станојевић 2013: 64, Ђурић 2019: 74), што значи да овај облик потпада под категорију игноратива (в. Пипер и др. 2005: 934-936). Међутим, познато је да се лексема неки каткада може употребити и да означи да је референт познат локутору. Наиме, Чудомировић у примеру Звао ме је неки човек ито ме стално прогања употребу облика неки објашњава потребом говорника „да нагласи (емотивну или неку другу) дистанцу према појму о којем је реч” (Чудомировић 2012: 325). У примеру Иван жели да отпева неку романсу исти аутор улогу заменице неки објашњава на следећи начин: „знам коју, али мислим да је лоша, безвредна”. Ово, међутим, није нужна интерпретација наведеног исказа. Пре ће бити да је у овде улога лексеме неки да сигнализује оно што Љ. Ђурић назива дискурсном непроминентношћу референта (Ђурић 2019: 75), а М. Ивић индиферативом (Ивић 2000: 141), будући да облик неки напросто сигнализује да романса о којој је реч није битна за даљи ток разговора, што не мора нужно да значи (иако не искључује) да је она лоша или безвредна. Дискурсна непроминентност је очигледна у примеру Неки мој друг је купио Хјундаи із0 где облик неки не значи да је дотична особа (говорников друг) непозната говорнику, нити да се говорник од ње емотивно дистанцира, него само то да она није битна за даљи ток приче.

\section{4. Детерминатив један у предикату}

У корпусу смо нашли неколико примера са копулативним реченицама у којима именичка синтагма са детерминативом један функционише као део предиката, па се, као таква, она на француски преводи неодређеним чланом. Следећи Лајонса (Lyons 1977: 185), говорићемо о употребама облика један у тзв. предикативним ${ }^{15}$ копулативним реченицама, у којима је синтагма на

\footnotetext{
${ }^{15}$ Поред предикативних постоје и еквативне копулативне реченице у којима су синтагме на позицији субјекта и именског предиката кореференцијалне (Марија је моја сестра.; Марко је професор којег сам јуче упознао.) - уп. Лајонс (1977: 185).
} 
позицији предиката нереференцијална. Овај тип употребе у нашем корпусу имају тзв. скаларне именице, тј. именице које садрже неку евалуативну компоненту, која им даје одређену експресивност (примери 22 и 23), а ако је употребљена нека нескаларна именица као у примеру (24), онда њу модификује неки скаларни придев који именичкој синтагми даје евалуативну значењску компоненту (уп. Ђурић 2019: 126-128).

(22) Ти си један угојени дегенерик! Мама, Зоран је разбио теглу са нашим слатком! - T’es un gros dégénéré ! Maman, Zoran a cassé notre pot de confiture !

(23) Ово стварно превазилази све границе. Станиславе, ти си један обични кретен! A, зашто ја? - Ça dépasse les bornes. Stanislav, tu n’es qu'un crétin! Pourquoi moi?

(24) Ово је један фин дечко, немаш шта да бринеш. - C'est un bon garçon. Tu n'as pas à t'inquiéter.

У србистичкој литератури (Ивић 1971: 114, Чудомировић 2012: 336) лексеми један уз експресивне евалуативне именице приписује се тзв. „експресивно-афективна функција". Овакво тумачење донекле је спорно будући да функцију лексеме један изводи из семантичког доприноса неког другог елемента синтагме - скаларне именице у примерима (22) и (23), односно скаларног придева у примеру (24) - тако да експресивност целе конструкције више зависи од именичког или придевског а мање од детерминативног члана синтагме. Пре ће бити да облик један у наведним копулативним конструкцијама функционише као нека врста интензификатора будући да се његовом употребом појачава експресивни набој именице (или придева) по продуктивном моделу вокативних конструкција с постпозицијом облика један (типа Кретену један!, Идиоте један!), дајући синтагми већу експресивност него што би је она имала без детерминатива. Ако се експресивно-афективна функција облика један у овом типу употребе и може бранити тиме што ће се том облику приписати функција интензификатора, теже је, међутим, одбранити став по којем би детерминатив један у овом типу употребе имао генеричку вредност. Наиме, Чудомировић (2012: 336-337) тврди да један у експресивно-афективној функцији (Грубијану један!), коју има и у копулативним конструкцијама типа $B u$ сте један грубијан, не указује на неодређеност појма него на „типичне карактеристике појма” (2012: 338) о којем је реч, односно, да се тада овај облик налази у генеричкој употреби. По нашем мишљењу, међутим, осим ако интерпретација копулативних реченица није еквативна, тј. не подразумева да су и субјекат и именски део предиката референцијално одређени (као у примеру Марко је Маријин брат.), именичка синтагма на позицији предиката копулативних реченица интерпретираће се или као својство, попут придева, као у примеру Марко је један грубијан, ${ }^{16}$ или референцијално, као у примеру: Марија је једна кретенка коју сам недавно упознао, у којем именичка синтагма 'једна кретенка коју сам недавно упознао'

\footnotetext{
${ }^{16}$ По моделу копулативних реченица с придевом, типа Марко је луд, где се субјекатском ентитету (Марку) приписује својство 'бити луд', тј. где се Марко сврстава у скуп лудих особа.
} 
означава конкретну индивидуу, па је копулативна реченица идентификујућа. ${ }^{17}$ Она свакако не може бити генеричка. Овде бисмо додали још нешто. Било да је реч о вокативним или њима еквивалентним копулативним конструкцијама, облик један уз скаларне (евалуативне) именице нема само функцију да појача интензитет својства означеног евалуативном именицом (или придевом) него и да сигнализује да је то својство нешто ново за саговорника или пак за самог говорника. ${ }^{18}$ Тако би се, уз примарну функцију која се састоји у увођењу новог референта у дискурс у неутралним контекстима (тј. у одсуству неке скаларне именице или придева), за детерминатив један могла везати и једна секундарна функција - 'увођење новог својства' - коју овај облик има у афективним контекстима, тј. у присуству неке скаларне именице и/или придева. У сваком случају, ваљало би подробније испитати интензификаторску функцију детерминатива један у неким будућим истраживањима.

\section{5. Закључак}

Детерминатив један и француски неодређени члан корелирају на плану превођења са српског на француски будући да имају бар два заједничка семантичка својства која су константно присутна у равни референцијалне употребе, а то су: увођење новог референта у дискурс, тј. референта непознатог саговорнику, и епистемичка неутралност у погледу познатости референта за говорника. У домену нереференцијалне употребе у којима се јавља као елемент именског дела предиката (Марко је једна будала) овим се обликом појачава интензитет, тј. афективни набој својства означеног скаларном (тј. евалуативном) именицом које се уводи као нова информација за саговорника. Но, и овде се именичка синтагма са обликом један може интерпретирати референцијално под условом да се именица модификује релативном реченицом која додатно спецификује субјекатски ентитет (нпр. Он је једна будала која ми се напила крви.). Најзад, иако за то немамо потврде у нашем корпусу, кореспонденција један-ип постоји и на равни генеричке употребе, будући да је један у генеричким реченицама могуће употребити само ако се реченицом изражава тзв. нормативна генеричност (Један центлмен отвара врата дамама.), која се у француском језику изражава неодређеним чланом, о чему смо већ писали у неким нашим претходним радовима (види Станојевић/Ђурић 2016).

\footnotetext{
${ }_{17}$ Један је овде маркер специфичности па није интензификатор за разлику од предикативне копулативне реченице Марко је један грубијан, где, у присуству скаларне именице - он то јесте.

${ }^{18}$ На пример, у ситуацији у којој би говорник, свестан неке своје заблуде или грешке, рекао самом себи: Будало једна!
} 


\section{ЛИТЕРАТУРА}

Ђурић 2019: Ljubica Đurić, Gramatikalizacija broja 'jedan'u srpskom kao balkanskoslovenskom jeziku u poređenju s francuskim: arealna i tipološka perspektiva, [doktorska disertacija], Filološki fakultet Univerziteta u Beogradu.

Ивић 1971: Милка Ивић, Лексема један и проблем неодређеног члана, Зборник Матице српске за филологију и лингвистику XIV/1, 103-118.

Ивић 2000: Milka Ivić, O odredbi izvestan, Lingvistički ogledi, tri. Beograd: Biblioteka XX vek, 137-148.

Лајонс 1977: John Lyons, Semantics, vol. 1. Cambridge: Cambridge University Press.

Маретић 1963: Tomo Maretić, Gramatika hrvatskoga ili srpskoga književnog jezika, Zagreb: Matica hrvatska.

Мразовић 2009: Павица Мразовић, Граматика српског језика за странще, Сремски Карловци, Нови Сад: Издавачка књижарница Зорана Стојановића.

Пипер и др. 2005: П. Пипер, И. Антонић, В. Ружић, С. Танасић, Љ. Поповић, Б. Тошовић, Синтакса савременог српског језика. Проста реченииа, Београд: Институт за српски језик САНУ, Београдска књига; Нови Сад: Матица српска.

Станојевић 2010: Веран Станојевић, О неким аспектима референцијалности у франуском и у српском језику, Интердисииплинарност и јединство савремене науке, у: Милош Ковачевић (ур.), том 1, Филолошке науке: зборник радова са научног скупа одржаног на Филозофском факултету Универзитета у Источном Сарајеву (Пале, 22-24. 05. 2009.), књига 4, Пале: Филозофски факултет, 123-134.

Станојевић 2013: Veran Stanojević, „Quelques aspects de l'indéfinitude en français et en serbe", Godišnjak Filozofskog fakulteta u Novom Sadu, XXXVIII/3, $59-71$.

Станојевић/Ђурић 2016: Veran Stanojević, Ljubica Đurić, Sur les indéfinis singuliers génériques en français et en serbe, Travaux de linguistique 72, $121-133$.

Стевановић 1981: Михаило Стевановић, Савремени српскохрватски језик I, Београд: Научна књига.

Чудомировић 2012: Јован Чудомировић, О полифункционалности лексеме један у српском језику, Научни састанак слависта у Вукове дане, 41/3, 319-346. 
Veran J. Stanojević

\title{
QUELQUES ASPECTS DE L’USAGE DU LEXÈME JEDAN EN SERBE PARLÉ ET SES ÉQUIVALENTS FRANÇAIS
}

\begin{abstract}
Résumé
Nous nous intéressons dans ce travail aux emplois non-numériques du lexème jedan en tant que déterminant du nom. Partant des équivalents français de jedan nous examinons les propriétés que cette forme partage avec l'article indéfini.

Mots clé: jedan, cardinal numéral, article indéfini, sémantique, le serbe, le français.
\end{abstract}

